\title{
EDUKASI PERTANIAN RAMAH LINGKUNGAN BERBASIS MIKROORGANISME INDIGENOUS PADA KELOMPOK TANI DI KOTA TARAKAN
}

\author{
Environmentally Friendly Farming Education Based On Indigenous Microorganism At \\ Farmers Group In Tarakan City
}

\author{
Siti Zahara ${ }^{*}$, Eko Hary Pudjiwati ${ }^{2}$, Amarullah $^{3}$, Ankardiansyah Pandu Pradana $^{4}$, \\ Nurmaisah $^{5}$, Nurjanah ${ }^{6}$ \\ 1,2,3,4,5,6 Jurusan Agroteknologi, Fakultas Pertanian, Universitas Borneo Tarakan \\ Jl. Amal Lama No. 1 Tarakan, 082138079174 \\ *e-mail korespondensi: szahara57@yahoo.co.id
}

\begin{abstract}
ABSTRAK
Budidaya tanaman hortikultura di kota Tarakan memiliki peluang besar karena permintaan pasar yang cukup tinggi. Namun usaha ini tidak lepas dari berbagai tantangan. Tantangan utamanya adalah upaya pengendalian Organisme Pengganggu Tanaman (OPT). Berbagai upaya pengendalian telah dilakukan oleh petani, seperti penggunaan pestisida kimia dan nabati. Solusi lain yang belum banyak diketahui oleh petani adalah penggunaan agens hayati (bakteri atau cendawan). Banyak petani di Kota Tarakan belum mengetahui perbedaan pestisida nabati dan hayati, maka perlu adanya kegiatan transfer ipteks yang dimiliki oleh Fakultas Pertanian UBT kepada petani di Kota Tarakan. Teknologi yang diberikan kepada petani dalam kegiatan adalah teknik perbanyakan dan teknik aplikasi bakteri indigenous sebagai pestisida hayati serta pembuatan demplot. Setelah pelaksanaan kegiatan ini; 1) petani dapat memanfaatkan mikroorganisme indigenous untuk usaha tani, 2) petani dapat membedakan serangan hama, bakteri patogen, cendawan patogen, dan virus patogen sehingga mampu memilih jenis pestisida yang spesifik, 3) petani dapat membedakan pestisida hayati dengan pestisida lainnya, dan mampu memproduksi pestisida hayati berbasis bakteri fungsional indigenous, 3) petani mengharapkan adanya kegiatan lain sejenis untuk mengatasi berbagai kendala dalam usaha tani, 4) perlu adanya dukungan dan kerjasama dari pihak terkait seperti Dinas Pangan, Pertanian dan Perikanan Kota Tarakan untuk menyelesaikan berbagai permasalahan usaha tani.
\end{abstract}

Kata Kunci: edukasi, indigenous, kelompok tani, mikroorganisme, ramah lingkungan

\section{ABSTRACT}

The cultivation of horticultural crops in the Tarakan City has a great opportunity because of the high market demand. But this business is not free from various challenges. The main challenge is efforts to control Plant Disturbing Organisms. Various control efforts have been carried out by farmers, such as the use of chemical and botanical pesticides. Another solution that is not widely known by farmers is the use of biological agents (bacteria or fungi). Many farmers in Tarakan City do not know the difference between botanical and biological pesticides, so there is need for science and technology transfer activities owned by the UBT Faculty of Agriculture to farmers in Tarakan City. The technology provided to farmers in this activity is the propagation techniques and indigenous bacterial application techniques as biological pesticides as well as making demonstration plots. After the implementation of this activity; 1) farmers can utilize indigenous microorganisms for farming, 2) farmers can distinguish pests, pathogenic bacteria, pathogenic fungi, and pathogenic viruses so that they can choose specific types of pesticides, 3) farmers can distinguish biological pesticides from other pesticides, and are able to produce indigenous pesticide based on indigenous functional bacteria, 3) farmers expect other similar activities to overcome various constraints in farm, 4) there needs to be support and cooperation from related parties such as The Food, Agriculture and Fisheries Office of Tarakan City to solve various farm problems.

Keywords: education, indigenous, farmers group, microorganism, environmentally friendly

\section{PENDAHULUAN}

Kota Tarakan terletak di bagian utara Indonesia, tepatnya di Provinsi Kalimantan
Utara. Menurut Badan Pusat Statistik Kota Tarakan tahun 2017 jumlah penduduk kota lebih dari 227.200 jiwa. Penduduk di kota 
ini memiliki beragam mata pencaharian, salah satunya adalah sebagai petani tanaman hortikultura. Budidaya tanaman hortikultura merupakan peluang besar karena permintaan di pasar akan produk hortikultura cukup tinggi. Namun usaha ini tidak lepas dari berbagai tantangan. Tantangan utama budidaya tanaman hortikultura di kota Tarakan adalah kondisi alam yang kurang mendukung, antara lain tidak adanya gunung berapi, curah hujan tinggi dan tingginya derajat kemasaman tanah (pH antara 3-5). Kondisi tanah yang masam juga menyebabkan masalah tersendiri. Pada tanah dengan $\mathrm{pH}$ rendah unsur kalium $(\mathrm{K})$, magnesium $(\mathrm{Mg})$, dan fosfor (P) tidak dapat diserap oleh tanaman karena terikat secara kimiawi (Barrow, 2017). Selanjutnya, curah hujan yang tinggi menyebabkan beberapa permasalahan seperti hilangnya lapisan atas tanah karena aliran permukaan, tergenangnya tanaman sehingga produksi tidak maksimal, dan meningkatkan kelembaban yang mendukung munculnya organisme penganggu tanaman (OPT) (Tripathy et al., 2018).

Berdasarkan hasil survei internal Fakultas Pertanian Universitas Borneo Tarakan pada tahun 2018, diketahui sebagian besar petani di Kota Tarakan belum mengetahui perbedaan jenis-jenis OPT. Lebih dari $60 \%$ petani belum memahami perbedaan kerusakan tanaman akibat serangan hama (serangga), bakteri, cendawan, dan virus. Ketidakpahaman tersebut seringkali menyebabkan keparahan serangan menjadi lebih tinggi, dan biaya yang dikeluarkan oleh petani juga menjadi lebih banyak.

Berbagai upaya pengendalian OPT telah dilakukan oleh petani, seperti penggunaan pestisida kimia sintetik dan pestisida nabati. Penggunaan pestisida kimia sintetik merupakan solusi yang cepat namun kurang ramah lingkungan. Bagheri et al. (2018) melaporkan penggunaan pestisida kimia sintetik secara terus menerus dapat menurunkan kualitas fisik, kimia, dan biologi tanah. Selanjutnya, penggunaan pestisida kimia sintetik juga dapat meracuni produk pertanian sehingga dapat membahayakan konsumen. Beberapa penyakit yang dilaporkan timbul akibat penggunaan pestisida kimia sintetik adalah kanker, sakit kepala berkelanjutan, keguguran pada ibu hamil, dan gangguan pencernaan (Cimino et al., 2017; Kim et al. 2017). Solusi lainnya yaitu menggunakan pestisida nabati yang diketahui lebih ramah lingkungan dan dapat dibuat sendiri oleh petani. Meskipun berbagai teknik tersebut telah dilakukan oleh petani, namun masalah OPT di Kota Tarakan masih menjadi masalah yang belum teratasi sepenuhnya.

Solusi lainnya yang belum banyak diketahui oleh petani di Kota Tarakan adalah penggunaan agens hayati (bakteri atau cendawan) untuk mengendalikan OPT di lapangan. Banyak petani di Kota Tarakan belum mengetahui perbedaan pestisida nabati dan pestisida hayati. Pestisida hayati adalah pestisida dengan bahan aktifnya terdiri dari mikroorganisme (bakteri atau cendawan) yang masih aktif. Kelebihan pestisida ini adalah aman bagi manusia dan lingkungan, tidak cepat hilang dari lingkungan, dan efektifitasya tinggi (Ivase et al., 2017). Saat ini Fakultas Pertanian Universitas Borneo Tarakan memiliki 3 isolat yang telah diuji mampu menghambat beberapa OPT sekaligus mampu memacu pertumbuhan tanaman. Ketiga isolat tersebut merupakan isolat indigenous yang diisolasi dari Kalimantan Utara dan telah diuji oleh Fakultas Pertanian UBT.

Berdasarkan uraian di atas maka perlu adanya kegiatan transfer ipteks yang 
dimiliki oleh Fakultas Pertanian UBT kepada para petani di Kota Tarakan. Teknologi yang akan diberikan kepada petani dalam kegiatan ini adalah teknologi hayati berupa teknik perbanyakan dan teknik aplikasi bakteri indigenous sebagai pestisida hayati. Kegiatan ini akan menjadi kegiatan pengenalan pestisida hayati berbasis bakteri fungsional indigenous yang pertama kali di Kota Tarakan. Selanjutnya, petani di Kota Tarakan akan mampu memproduksinya secara mandiri dan berkelanjutan sehingga akan menghemat pengeluaran petani untuk membeli pestisida, mengurangi kerusakan lingkungan dan polusi di lahan pertanian, juga merupakan solusi produksi produk pertanian yang sehat dan aman.

\section{METODE}

Kegiatan dilaksanakan dengan metode penyuluhan, pelatihan, dan pendampingan kepada kelompok mitra. Seluruh rangkaian kegiatan ini dilaksanakan di Kampus Fakultas Pertanian Universitas Borneo Tarakan oleh tim beserta 2 mahasiswa dan tiga orang dosen muda Fakultas Pertanian Universitas Borneo Tarakan. Secara terperinci pelaksanaan kegiatan adalah:

1. Sosialisasi dan Penyuluhan

Penyuluhan dilakukan dengan metode ceramah dan dilengkapi dengan dukungan multimedia berupa paparan materi (menggunakan program Microsoft Power Point) yang dilengkapi dengan video dan audio. Materi yang diberikan meliputi pengenalan hama dan patogen serta perbedaan gejala serangan yang ditimbulkannya, teknik penanganan keracunan akibat pestisida, pengenalan pestisida hayati (keunggulan, teknik perbanyakan, dan teknik aplikasinya), serta cara mudah membuat pestisida hayati oleh petani.
2. Pembuatan demonstration plot (Demplot)

Tim menanam tanaman hortikultura sawi dan cabai yang umum dibudidayakan oleh petani di Kota Tarakan dan diberi perlakuan menggunakan POC, dan pestisida hayati (bakteri). Setelah itu petani diajak melihat secara langsung perbedaan pertumbuhan dan hasil tanaman yang diberi perlakuan tersebut. Tujuan dari pembuatan demplot adalah petani dapat melihat secara nyata kelebihan pestisida hayati sehingga lebih mudah menanamkan believe baru bahwa pestisida hayati lebih menguntungkan bagi petani dan konsumen.

3. Evaluasi

Pelaksanaan evaluasi dilakukan dengan membuat kuisioner yang akan diisi oleh para peserta kegiatan ini (petani dan PPL).

\section{HASIL DAN PEMBAHASAN .}

\subsection{Pembuatan Demplot}

Pembuatan Demplot dilakukan oleh Tim Pelaksana dengan melibatkan dua orang mahasiswa dan 3 orang Dosen Muda yang pelaksanaannya 40 hari sebelum kegiatan sosialisasi dan penyuluhan. Demplot tanaman sawi dan cabai dibuat di lahan percobaan Fakultas Pertanian Universitas Borneo Tarakan. Pembuatan demplot dimaksudkan untuk memberikan contoh kepada para petani yang tergabung dalam kelompok tani mitra mengenai budidaya tanaman hortikultura yang ramah lingkungan.

Tanaman hortikultura yang diusahakan pada demplot ini dibudidayakan tanpa menggunakan bahan kimia sama sekali. Sumber nutrisi yang dibutuhkan oleh tanaman diberikan melalui penambahan bahan organik (pupuk kandang ayam sebagai pupuk dasar, POC (Pupuk Organik Cair) serta bakteri. Selain itu pembuatan demplot juga dimaksudkan untuk 
menunjukkan kepada para petani perbedaan antara pertumbuhan dan hasil tanaman yang diberi POC dengan yang disemprot bakteri (sebagai biofertilizer dan pestisida hayati).

Adanya demplot ini petani dapat melihat secara nyata kelebihan penggunaan mikroorganisme (bakteri) sehingga lebih mudah menanamkan believe baru bahwa penggunaan bakteri lebih menguntungkan bagi petani dan konsumen karena dapat berperan sebagai pestisida hayati dan biofertilizer bagi tanaman.

Pembuatan demplot diawali dengan pengolahan tanah dan pembuatan petak demplot. Sebanyak delapan petak demplot berukuran masing-masing 2 x 5 meter dan jarak antar petak sekitar $30 \mathrm{~cm}$ disiapkan sebelum penanaman (Gambar 1.). Setelah pengolahan tanah, satu minggu sebelum penanaman lahan diberi pupuk kandang ayam sebagai pupuk dasar. Empat petak dari delapan petak yang sudah dibuat ditanami sawi dan empat petak lainnya ditanami cabai rawit.

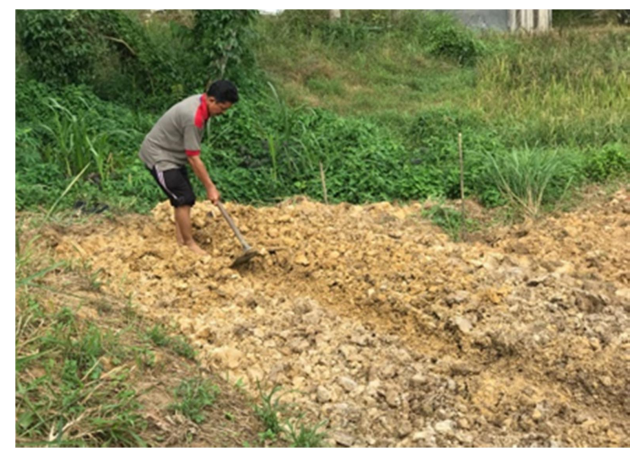

Gambar 1. Pembuatan Petak Demplot

Dua petak tanaman sawi dan cabai yang ditanam pada demplot kemudian diberi perlakuan POC dan dua petak lainnya hanya disemprot dengan bakteri.

Sebelum bibit sawi dan cabai ditanam, bibit diseleksi agar dapat tumbuh menjadi tanaman yang seragam di lapangan (Gambar 2.). Seleksi bibit dilakukan pada hari yang sama dengan penanaman dan selanjutnya bibit segera ditanam.

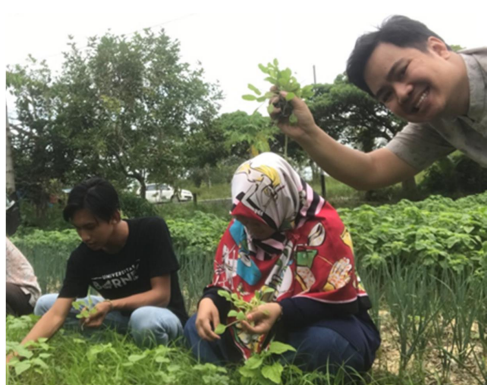

Gambar 2. Seleksi Bibit

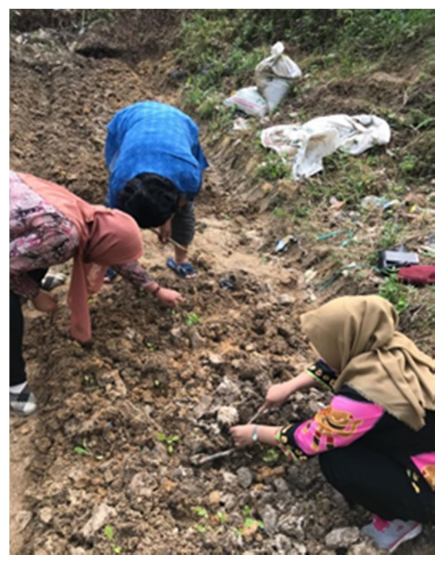

Gambar 3. Penanaman

Penanaman dilakukan di sore hari, dengan cara menanam bibit pada lubang tanam yang dibuat (Gambar 3.). Jarak tanam yang digunakan untuk sawi adalah $20 \times 20 \mathrm{~cm}$ dan $30 \times 60 \mathrm{~cm}$ untuk cabai rawit. Setelah penanaman, di sekitar bibit ditaburi pupuk kandang dan dilakukan penyiraman untuk menjaga kelembaban tanah disekitarnya (Gambar 4.).

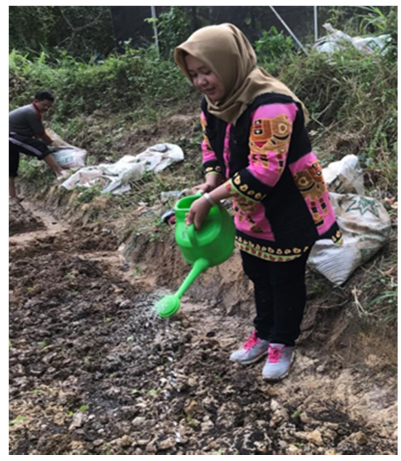

Gambar 4. Penyiraman dan Penaburan Pupuk Kandang Ayam

Kedelapan petak demplot masingmasing ditanami dengan tanaman cabai sebanyak empat demplot dan empat petak 
demplot lainnya ditanami sawi. Dua petak dari masing-masing petak tanaman tersebut disemprot dengan POC dan dua petak lainnya disemprot dengan larutan yang mengandung bakteri. Penyemprotan mulai dilakukan dua minggu setelah penanaman di sekitar tanaman yang sebelumnya telah dibersihkan dari gulma (Gambar 5.). Penyemprotan secara rutin terus dilakukan dengan interval waktu dua minggu sekali hingga dua minggu sebelum panen.

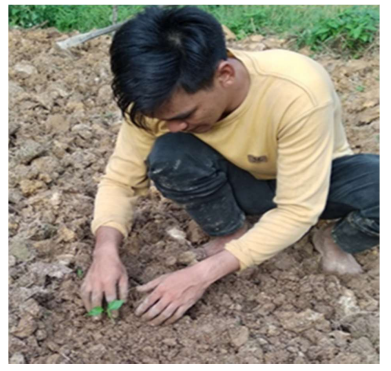

Gambar 5. Persiapan Aplikasi POC dan Bakteri

Berdasarkan demplot yang dibuat terlihat bahwa tanaman sawi yang hanya disemprot bakteri pertumbuhannya tidak berbeda dengan yang disemprot POC (Gambar 6 A dan B.).

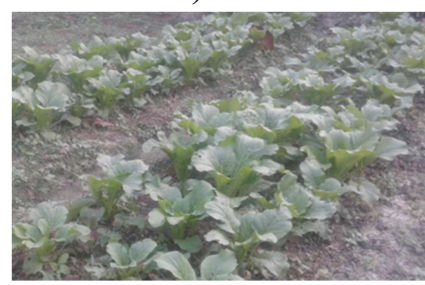

A

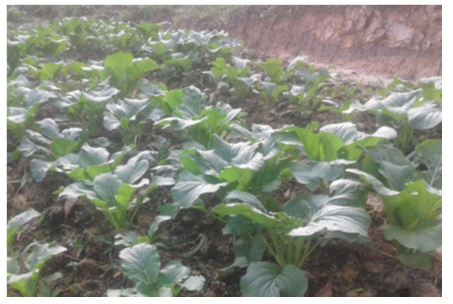

B

Gambar 6. Petak Tanaman Sawi (A= disemprot bakteri; $\mathrm{B}=$ disemprot $\mathrm{POC}$ )

Begitu pula dengan tanaman cabai yang disemprot bakteri, juga mampu menghasilkan pertumbuhan yang sama baiknya dengan yang disemprot POC (Gambar 7 A dan B.).

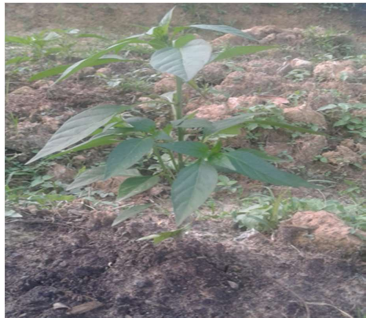

$\mathbf{A}$

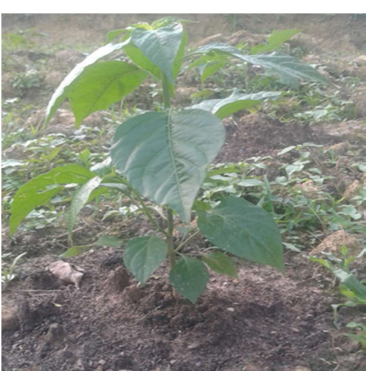

B

Gambar 7. Tanaman Cabai $(\mathrm{A}=$ disemprot bakteri; $\mathrm{B}=$ disemprot $\mathrm{POC})$

Hal ini menunjukkan bahwa bakteri yang disemprotkan selain berperan sebagai biopestisida atau pestisida hayati yang mampu mengendalikan OPT juga berperan sebagai biofertilizer yang mampu memacu pertumbuhan tanaman. Penyemprotan bakteri pada tanaman sawi dan cabai mampu menghasilkan pertumbuhan tanaman seperti tanaman yang disemprot dengan POC. Menurut Vessey (2003), biofertilizer merupakan suatu bahan yang mengandung mikroorganisme bermanfaat untuk meningkatkan kesuburan tanah dan kualitas hasil tanaman melalui peningkatan aktivitas biologi yang akhirnya dapat berinteraksi dengan sifat fisik dan kimia tanah. Sehingga peran POC dalam menyediakan nutrisi bagi tanaman dapat digantikan oleh bakteri.

\subsection{Sosialisasi dan Penyuluhan}

Kegiatan dilaksanakan di kampus Fakultas Pertanian Universitas Borneo 
Tarakan. Dihadiri oleh 21 petani yang tergabung dalam kelompok tani dan kelompok wanita tani serta 9 orang penyuluh pertanian (PPL) di Kota Tarakan. (Gambar 8 A dan B.).
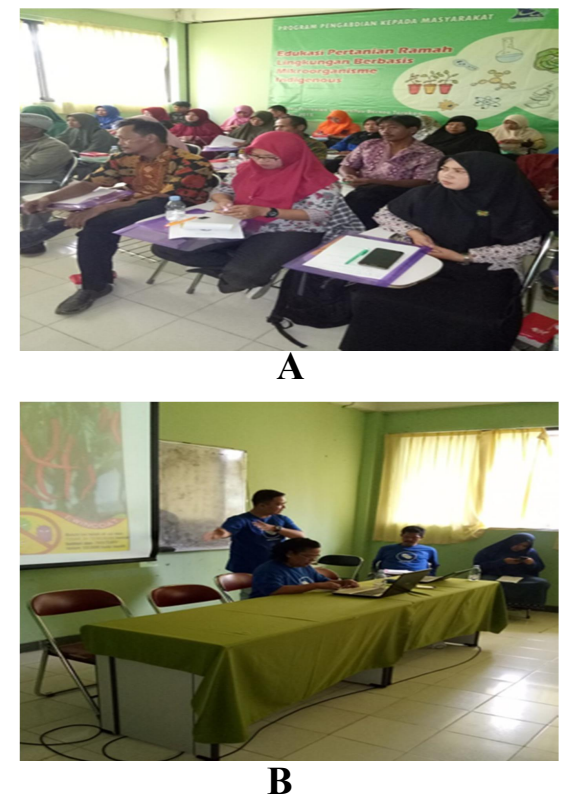

Gambar 8. Sosialisasi dan Penyuluhan

Tim Pelaksana dalam kegiatan ini dibantu oleh tiga orang dosen muda serta dua orang mahasiswa. Selama kegiatan sosialisasi dan penyuluhan, Tim Pelaksana menyampaikan materi yang berkaitan dengan pertanian ramah lingkungan yang berbasis mikroorganisme indigenous. Tim Pelaksana juga mensosialisasikan beberapa hasil penelitian yang telah dilakukan mengenai pemanfaatan mikroorganisme indigenous sebagai biopestisida dan pupuk hayati (biofertilizer). Materi lain yang juga disampaikan kepada petani adalah pengenalan hama dan patogen serta perbedaan gejala serangan yang ditimbulkannya, teknik penanganan keracunan akibat pestisida, pengenalan pestisida hayati (keunggulan, teknik perbanyakan, dan teknik aplikasinya), serta cara mudah membuat pestisida hayati oleh petani.
Selain penyampaian materi di kelas, praktik cara memperbanyak mikroorganisme juga dilakukan di Laboratorium Perlindungan Tanaman, Fakultas Pertanian Universitas Borneo Tarakan. Para peserta diberi kesempatan untuk praktik secara langsung dengan pendampingan dari Tim (Gambar 9 A dan B).

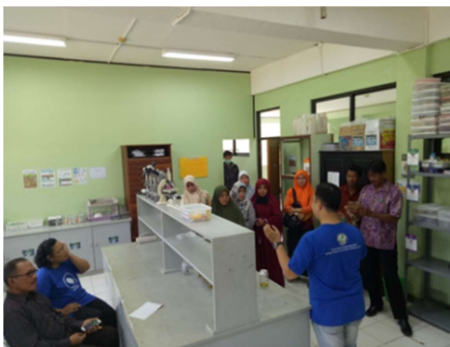

A

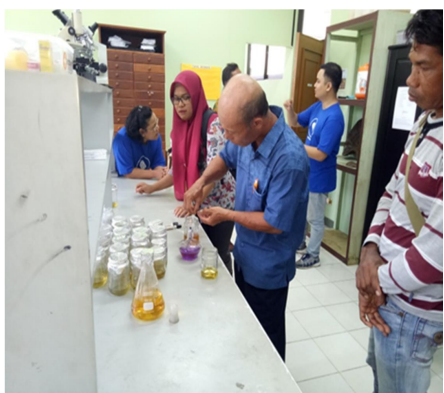

B

Gambar 9. Kegiatan di Laboratorium (A dan B)

Setelah penyampaian materi sosialisasi/penyuluhan di kelas serta pendampingan di laboratorium, para petani dan PPL kemudian mengunjungi demplot yang telah dibuat oleh Tim untuk melihat secara langsung pertumbuhan tanaman sawi dan cabai yang telah diberi perlakuan POC dan bakteri (Gambar 10 A dan B).

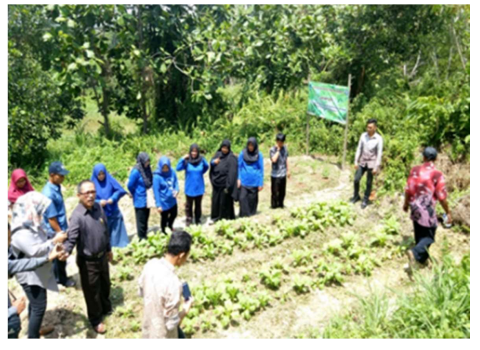

A 


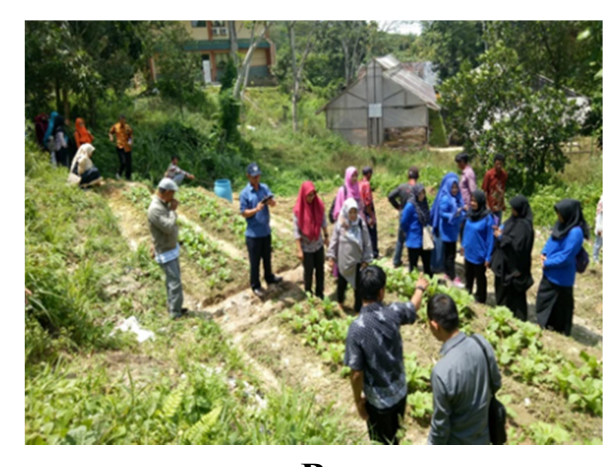

B

Gambar 10. Kunjungan petani dan PPL ke Demplot (A dan B)

Selama kegiatan dilakukan terlihat besarnya perhatian dan semangat para petani dan PPL mengikuti serta menerima setiap informasi yang disampaikan oleh Tim Pelaksana. Hal dikarenakan materi sosialisasi dan penyuluhan yang disampaikan memang sangat dibutuhkan oleh petani di Kota Tarakan untuk menjadi solusi bagi pernasalahan dalam menjalankan usaha tani.

Setelah pelaksanaan kegiatan ini: 1) $100 \%$ petani mampu membedakan serangan akibat hama, bakteri patogen, cendawan patogen, dan virus patogen sehingga seluruh petani mampu memilih jenis pestisida yang spesifik berdasarkan jenis OPT yang menyerang; 2) $100 \%$ petani dapat memberikan pertolongan pertama pada kejadian keracunan pestisida; 3) $100 \%$ petani dapat membedakan pestisida hayati dengan pestisida lainnya, dan mampu memproduksi secara mandiri pestisida hayati berbasis bakteri fungsional indigenous; dan 4) Petani mampu memproduksi pestisida hayati berbasis bakteri fungsional indigenous.

Selain itu dari pelaksanaan evaluasi terhadap kegiatan yang dilakukan, Tim Pelaksana mendapatkan beberapa permasalahan yang masih dihadapi oleh petani di Kota Tarakan dalam aktifitas usaha tani. Hasil evaluasi ini akan menjadi
(Halaman 23-30)

dasar bagi Tim untuk melaksanakan kegiatan pengabdian selanjutnya. Permasalahan tersebut adalah: 1) Ketersediaan pupuk yang tidak lancar; 2) Hama dan penyakit tanaman yang sulit dikendalikan; 3) Kurangnya modal usaha tani; 4) Kondisi lahan yang tidak subur; 5) Ketersediaan alat-alat pertanian (seperti alat pengolahan tanah) yang masih sangat terbatas; 6) Kurangnya pendampingan atau koordinasi oleh PPL kepada petani.

Berdasarkan hasil evaluasi juga, Tim mengetahui informasi dan pengetahuan lainnya yang dibutuhkan petani di Kota Tarakan, yaitu: 1) Teknologi pasca panen dan pengolahan hasil pertanian; 2) Upaya penguatan kelembagaan tani; 3) Teknologi peningkatan kesuburan tanah; 4) Teknologi pengendalian hama dan penyakit; dan 5) Teknologi budidaya yang baik dan benar.

Hasil evaluasi dari kegiatan pengabdian yang telah dilaksanakan oleh Tim menunjukkan bahwa kegiatan edukasi pertanian ramah lingkungan yang dilakukan oleh Tim Pelaksana Kegiatan Pengabdian pada Masyarakat Fakultas Pertanian Universitas Borneo Tarakan merupakan salah satu kegiatan yang sangat dibutuhkan oleh para petani dan PPL di Kota Tarakan. Selain itu petani juga masih mengharapkan adanya kegiatan sejenis guna mengatasi berbagai permasalahan dalam usaha tani.

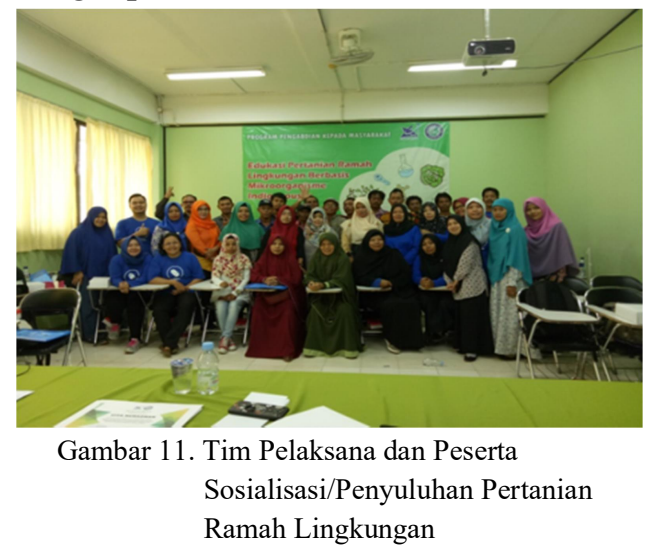




\section{PENUTUP}

Setelah pelaksanaan kegiatan edukasi pertanian ramah lingkungan maka: Petani memiliki pengetahuan mengenai pemanfaatan mikroorganisme indigenous dalam usaha tani. Petani mampu membedakan serangan akibat hama, bakteri patogen, cendawan patogen, dan virus patogen sehingga seluruh petani mampu memilih jenis pestisida yang spesifik berdasarkan jenis OPT yang menyerang. Petani dapat membedakan pestisida hayati dengan pestisida lainnya, dan mampu memproduksi secara mandiri pestisida hayati berbasis bakteri fungsional indigenous. Petani masih mengharapkan adanya kegiatan yang sejenis guna mengatasi berbagai kendala lainnya dalam usaha tani. Perlu adanya dukungan dan kerjasama dari pihak yang terkait seperti Dinas Pangan, Pertanian dan Perikanan Kota Tarakan dalam pelaksanaan sosialisasi dan penyuluhan pertanian lainnya serta kerja sama untuk menyelesaikan berbagai permasalahan dalam usaha tani di Kota Tarakan.

\section{UCAPAN TERIMA KASIH}

Ucapan terima kasih disampaikan kepada Lembaga Penelitian dan Pengabdian pada Masyarakat Universitas Borneo Tarakan yang telah memberikan kesempatan dan mendanai pelaksanaan kegiatan pengabdian ini.

\section{DAFTAR RUJUKAN}

Bagheri A, Emami N, Allahyari MS, dan Damalas CA. 2018. Pesticide handling practices, health risks, and determinants of safety behavior among Iranian apple farmers. Human and Ecological Risk Assessment. $10(2): 1-15$.

Barrow N. 2017. The effects of $\mathrm{pH}$ on phosphate uptake from the soil. Plant and Soil. 410(2):401-410.

Cimino AM, Boyles AL, Thayer KA, dan Perry MJ. 2017. Effects of neonicotinoid pesticide exposure on human health: a systematic review. Environmental Health Perspectives. 125(2):155-162.

Ivase TJ-P, Nyakuma BB, Ogenyi BU, Balogun AD, dan Hassan MN. 2017. Current status, challenges, and prospects of biopesticide utilization in Nigeria. Acta Universitatis Sapientiae, Agriculture and Environment. 9(1):95-106.

Kim K-H, Kabir E, dan Jahan SA. 2017. Exposure to pesticides and the associated human health effects. Science of The Total Environment. 575(1):525-535.

Tripathy M, Rout M, dan Das H. 2018. Relationship of Climatic Factors with Incidence of Major Insect Pest of Teak Seedlings at Coastal Odisha, India. Current Microbiolology and Applied Science. 7(2):3144-3151.

Vessey JK. 2003. Plant growth promoting rhizobacteria as biofertilizers. Plant and Soil. 255(2):571-586. Doi: 10.1023/A:1026037216893. 
